\title{
100 Days of Muhyiddin's Government Leadership: A Manifestation of the Continuity of Paternalism Values
}

\author{
Lutfan Jaes $^{\text {a }}$, Nurul Aimi Razali ${ }^{\mathrm{b}}$, Asyraf Maula Mohd Yusof ${ }^{\mathrm{c}}$ and Khairul Azman Mohd Suhaimy ${ }^{\mathrm{d}}$ \\ a,b,c,d \\ Pusat Pengajian Umum dan Kokurikulum, Universiti Tun Hussein Onn Malaysia, \\ 86400 Parit Raja, Batu Pahat, Johor
}

Article History: Received: 11 January 2021; Accepted: 27 February 2021; Published online: 5 April 2021

\begin{abstract}
This article attempts to describe Muhyiddin in leading the Pakatan Nasional Government (PN), especially in the era of Covid-19 pandemic management. It is traced through the role of Asian Values which are believed to shape the leadership character in his administration as the 8th Prime Minister of Malaysia. The stance on values and dimensions was referred based on the highlights of past literatures which stated that Asian countries have their own set of unique ideologies. It was then developed through the observation of one hundred (100) days of Muhyiddin's administration. Content analysis was applied as a research design aimed at identifying and then describing his significant speech text passages. The analysis looks at Paternalistic Leadership in the tendencies of "Work Ethics", "Society", "Power Orientation", and "Family" value dimensions. These four dimensions are often discussed by scholars in underlying the leadership style of Asian leaders. Data encoding was performed using the ATLAS software. The results show that Muhyiddin has indeed applied paternal values in governing. He managed to incorporate these values indirectly in the local wisdom of the community by manipulating those values by adapting to current needs. Muhyiddin does so with the soothing values of paternalism while shaping the development of the country more pragmatically and effectively. In conclusion, the restoration of the local wisdom values has become a factor driving the significant progress of Malaysia's post-PH Government continuous development.
\end{abstract}

Keywords: Muhyiddin, Asian value, paternalistic leadership, local wisdom

\section{Introduction}

Muhyiddin is the 8th Prime Minister of Malaysia who was appointed on 29th February 2020 and sworn in on 1st March 2020. It happened in a unique Malaysian political scenario when Mahathir unexpectedly resigned as the 7th Prime Minister. From then on, Muhyiddin's political destiny changed in the blink of an eye. However, this paper does not intend to describe the chronology of his leadership transition but rather focuses on the evaluation of value elements throughout the 100 days of rule.

This silent figure is seen trying to prove himself worthy of being the Prime Minister of Malaysia even though "he is not the choice of the majority of the people". Muhyiddin strives to mobilize pragmatic actions with effective leadership values and styles in order to achieve the planned mission and vision. The mandate entrusted by the Yang DiPertuan Agong was boldly accepted, undertaken extraordinarily, and implemented effectively. Muhyiddin, in several discussions, has been debated as a leader who is less talkative, less political, and rarely criticizes his opposition. Therefore, comfortably placing himself with a high value of humility. However, Akbal (2020) in Berita Harian stated that "the kick of the political world seems to be ingrained in Muhyiddin's blood, both from friends and opponents, thus becoming a tonic to stay focused on governing the country and not just playing politics". His leadership as well as the government during the first 100 days was seen as brave and successful. It is especially in facing the challenges and trials of Covid-19 along with the people. It became more well-known when his leadership during this crisis was seen using the local wisdom approach. In the context of this writing, the local wisdom conveyed by its leaders tries to be extended to a tendency to lead with paternal style and values which is a principal or system governing or controlling a country, a group of workers and so on based on the relationship between a father and a son. Paternalism is a paternalistic leadership style in which strong dominance is combined with fair attention and consideration (Westwood \& Chan, 1992).

\section{Research Problem}

Muhyiddin was appointed as the 8th Prime Minister in a different atmosphere and manner than the previous Prime Minister. Although his appointment was legal in accordance with the law, the accusations of "back door government" and "not the people's choice" had to be borne in his government. In the political context, it needs a solid explanation for its political rivals and a convincing statement to all Malaysians. Adding to the challenges in his government leadership is when Malaysia and most countries in the world are hit by the Covid-19 pandemic. It has a profound effect on all economic and social activities of the country. Society panics and partially loses its job. The country's economy seems to have stopped and some remedial actions cannot be done immediately due to the restrictions of social movements and so on. In a more personal context, Muhyiddin is also a recently cured cancer fighter and should need a lot of rest. Therefore the recipe for failure in leading was already in sight. However, that did not happen. The social, economic, and political challenges have been handled so well and calmly. He even gained international recognition, especially in dealing with pandemic. 
As such, the leadership and development implemented by a country cannot be separated from the cultural patterns practiced by its leaders and members of society. It is related to the commitment of both parties, namely those who lead and those who are led. In this case, common sense which is the socio-cultural inherited by the society of a country defines the next form of leadership development planned.

Wisdom is a philosophy related to the knowledge that is radiated through the cultural values of a society. Accordingly, local wisdom can be understood as a human effort to use his intellect to act and behave towards something, object or event in a particular space (Shafwan, 2013). In the context of this writing, the terms of values that underlie local wisdom as well as the dimensions of values to be discussed come from the Asian Value debate. Asian values are based on the belief that Asian countries have a unique set of ideologies that reflect the culture of the region and its respective history.

Therefore, this article begins with the assumption that the value of local wisdom gives a distinct impact in one's leadership if properly manipulated. This is because the main agenda of this article is to try to answer the following questions:

1. Is it true that local cultural values underpinned Muhyiddin's leadership in the first 100 days of his rule?

2. What is the tendency of values in Muhyiddin's government?

3. Next relate these development actions as the paternal values of a leader in leading his country?

\section{Literature Review}

The style and character of leadership associated with the concept of culture and local wisdom in leading development is observed to be still less studied. Not to mention when it is associated to the idea of paternalistic leadership. Cultural-value variables such as values, norms, attitudes, worldviews, traditional beliefs, and more are used as guiding objects.

Values are the essence of culture. It serves as a guideline, bond, measure, action, practice, perception, judgment and so on. Values are defined as beliefs that motivate a person or an institution to act according to choices based on the core values of society. Thus, value is the basic guide and confidence for an action, especially to the goal to be achieved in a certain period (Mustafa, 1994; Mohd Tap et al., 1993).

In conducting this study, the writing refers to an empirical study conducted by So Young Kim (2010). The author stated that there are 4 values or dimensions that are often discussed about the values of society in Asia. These values are family values, racial and societal values, power oriented values and work ethic values.

While Farh and Cheng (2000), paternalistic leadership is "a style of leadership that combines discipline, power and paternity". Aycan (2015) stated that paternal leadership is practiced in a society that is collective and practices authority. It also refers to the relationship between leaders and followers where leaders provide care, supervision, and guidance to followers in their professional and personal lives through means of care as would a father to his child and in return expect loyalty and respect from their followers. Through this leadership style, the chief or leader will be involved in the lives of their followers as expected by a collective society. Followers assume that it shows one of the ways in which the chief or leader provides care as well as protection to his followers (Jackson, 2016).

The fatherly kindness shows that the chief or leader naturally has a genuine concern for the welfare of his followers. While in return, followers express loyalty to their leaders due to the respect and appreciation that arises in them (Jackson, 2016). This leadership style is still a practice and is seen to be effective in most business cultures such as in the Middle East, Asia Pacific, and Latin America (Farh et al., 2006: Martinez, 2003). However, this type of leadership is perceived poorly by the Western society, where it is considered "a form of hidden and dangerous discrimination" (Colella et al., 2005: 26).

The highlights of the above literatures verifies what is happening to Muhyiddin's current leadership. Malaysians honorably allow a veteran politician of not their choice to lead them after being approved by the Yang DiPertuan Agong, while he represents Parti Pribumi Bersatu Malaysia (BERSATU), a new 3-year-old party that used to under Pakatan Harapan (PH) which has more experienced and dominant parties, namely Democratic Action Party (DAP) and Parti Keadilan Rakyat (PKR). Now with some changes in the country's political structure, Muhyiddin is leading Perikatan Nasional (PN) which consists of dominant and experienced parties such as Barisan Nasional (BN) and Parti Islam Se-Malaysia (PAS).

\section{Muhyiddin and Value System}

Muhyiddin Muhammad Yassin was born on 25 May 1947 in Muar, Johor. Hailing from a family of renowned religious people, he is one of the 47 children (one father, different mothers) of the famous scholar in Muar, Muhammad Yassin Muhammad (Cikgu Md Yassin). He received his early education at Sekolah Melayu Bandar Maharani and Sekolah Kebangsaan Ismail. He then received his secondary education at the Government English School before continuing his studies at the University of Malaya in the field of Economics and Malay Studies.

According to Tun Sheikh Engku Bendahara (2010), Muhyiddin was not categorized in the smart students group. He was an ordinary student but diligent and hardworking. He inherited many things from his father, but not in the matter of lectures because his father was a very eloquent scholar and loved by many. However, Muhyiddin 
inherited the nature of humility and sharp thinking, very thoughtful, and content when speaking with the right arguments.

Muhyiddin's biological mother is Hajah Khadijah Hj Kassim. All Muhyiddin's siblings live in their own house with their respective mothers. Yet they are close and neighbors with each other. This large family lived together affectionately and warmly. In their residential area, a private high school was developed which was famous among the Malays with low income back then. The existence of this school helped those who could not afford to send their children to government or English schools.

Next, according to Tun Sheikh Engku Bendahara's blog post in describing the value education received by Muhyiddin and his siblings are as follows:

"The surprising thing as a result of the interview with the large family (Muhyiddin) is the achievement of each individual (siblings) who have become independent, was not helped by their family or brother and sister anymore. This is because the foundation of teaching and education was so strong given by their father that it was almost accepted as a will. They were forbidden to take advantage and ask for family help after reaching adulthood and can be independent. They were educated to be unselfish, united, and cooperative, but they were strictly forbidden from abusing their position, corruption, greed, and persecuting people. These good values turned out to be the attitude practiced by Muhyiddin. Although he in in office and in a high position, he is not biased and not choose cronies especially from his own family members. Each had known the message of their late father and each felt ashamed to ask for the help of relatives and siblings who had succeeded. It is considered very sensitive if they intend to accumulate riches or amass wealth in a non-poverty situation. They are very aware that their father likes them to be modest people even in the situation of being the Prime Minister or a millionaire" (Tun Sheikh Engku Bendahara, 2016).

Because of the family background as well as the exposure of the value system applied since childhood, the initial assumption is presented that Muhyiddin is a strong leader with local wisdom. The strengthening of his character that comes from the image of the family has enhanced the community's confidence to elevate him as a credible and dependable leader. Thus providing a solid platform to be in its current position.

Muhyiddin's early political involvement began in 1971 as a regular member of UMNO Pagoh division before being appointed as Pagoh UMNO Youth Chief and then UMNO division in 1976. Muhyiddin contested as Member of Parliament for Pagoh (1978) and retained the seat until 1982. He was previously appointed Parliamentary Secretary in the Ministry of Foreign Affairs and later became Deputy Minister in the Ministry of Federal Territories and then the Ministry of Trade and Industry.

In the 1986 general election, Muhyiddin contested and won the Bukit Serampang constituency seat in the Johor State Assembly. It opened up space for him to serve in his own state and become the Menteri Besar of Johor until May 6, 1995. However, Muhyiddin returned to contest in the Pagoh parliament (1965) and became active again at the federal level. He held the cabinet as Minister of Youth and Sports (1995-1999), Minister of Consumer Affairs (1999-2004), Minister of Agriculture and Agro-based Industry (2004-2008) and Minister of International Trade and Industry (2008-2009). He was later appointed Deputy Prime Minister and Minister of Education in the era of Najib Razak, the sixth Prime Minister of Malaysia (2009).

Tun Musa Hitam, the fifth Deputy Prime Minister of Malaysia stated that Muhyiddin has a high fighting spirit, straight, and loyal. Tun Ghafar Baba, the sixth Deputy Prime Minister of Malaysia, said Muhyiddin looked low profile, but is knowledgeable without arrogance. In fact, Tun Mahathir, the fourth and seventh Prime Minister of Malaysia in his sarcastic words said he does not need people who think too much. What he really needs and really appreciates is people who think about implementation seriously and professionally. This is because he already has many leaders who can come up with brilliant ideas but do not know how to solve them. At that time, Mahathir was close and seemed proud of Muhyiddin's performance who always managed to implement big ideas without many problems and questions.

Muhyiddin is clearly a leader who is not very prominent. Until no one expected that this figure would be able to stand as the eighth Prime Minister of Malaysia. However, with the trust already in hand, it becomes his responsibility to lead the development of the country and its society. Every society must be allowed to find its best form and process according to its own mould.

Society in East Asia should have its own set of values in developing and managing society and country in its own way without having to be forced by external values, especially from the West. In this case, Mahathir stated:

"Asian values are Asian values. American values are American values. The two can meet and from that meeting there may be an understanding and appreciation of the wisdom of the other party and hopefully there will be a merger between all good values and rejection of bad or evil values. Let us admit that no one has a monopoly on wisdom."

(Mahathir, 2003)

\section{Methodology}

The research methodology involved a qualitative approach. Data analysis and data encoding used the concept of Computer Analysis Qualitative Data Analysis (CAQDAS). The Archive for Technology, the Life World and Everyday Language. Text Interpretation (ATLAS).ti version 8 software was used for this purpose. 
Wilson and Arnold (1964) in Abdul Mua'ti (2007) stated that "speech is an inspiration that is triggered, channeled, and expressed through thoughts, voices, and body movements that stimulate the audience and the speaker himself which sometimes affects the thoughts, feelings, and actions". The following is Muhyiddin's Speech Text Document as in Table 1.

Table 1: Muhyiddin's Speech Text Document

\begin{tabular}{|c|c|c|c|c|}
\hline Code & Title of Speech Text Document & Type of Text & Date & Venue \\
\hline S1 & $\begin{array}{l}\text { Speech by YAB Tan Sri Dato' Hj } \\
\text { Muhyiddin bin Hj Mohd Yassin - } \\
\text { Prime Minister } \\
\text { "Rayuan Kepada Rakyat Malaysia" }\end{array}$ & Political & 02 March 2020 & Putrajaya \\
\hline S2 & $\begin{array}{l}\text { Speech by YAB Tan Sri Dato' Hj } \\
\text { Muhyiddin bin Hj Mohd Yassin - } \\
\text { Prime Minister } \\
\text { "Announcement of Formation of } \\
\text { New Government Cabinet" }\end{array}$ & Political & 09 March 2020 & Putrajaya \\
\hline S3 & $\begin{array}{l}\text { Speech by YAB Tan Sri Dato’ Hj } \\
\text { Muhyiddin bin Hj Mohd Yassin - } \\
\text { Prime Minister }\end{array}$ & Covid-19 & 13 March 2020 & Putrajaya \\
\hline S4 & $\begin{array}{l}\text { Speech by YAB Tan Sri Dato’ Hj } \\
\text { Muhyiddin bin Hj Mohd Yassin - } \\
\text { Prime Minister }\end{array}$ & Covid-19 & 16 March 2020 & Putrajaya \\
\hline S5 & $\begin{array}{l}\text { Speech by YAB Tan Sri Dato’ Hj } \\
\text { Muhyiddin bin Hj Mohd Yassin - } \\
\text { Prime Minister }\end{array}$ & Covid-19 & 18 March 2020 & Putrajaya \\
\hline S6 & $\begin{array}{l}\text { Speech by YAB Tan Sri Dato’ Hj } \\
\text { Muhyiddin bin Hj Mohd Yassin - } \\
\text { Prime Minister }\end{array}$ & Covid-19 & 25 March 2020 & Putrajaya \\
\hline S7 & $\begin{array}{l}\text { Speech by YAB Tan Sri Dato’ Hj } \\
\text { Muhyiddin bin Hj Mohd Yassin - } \\
\text { Prime Minister }\end{array}$ & Covid-19 & 10 April 2020 & Putrajaya \\
\hline S8 & $\begin{array}{l}\text { Speech by YAB Tan Sri Dato’ Hj } \\
\text { Muhyiddin bin Hj Mohd Yassin - } \\
\text { Prime Minister }\end{array}$ & Covid-19 & 23 April 2020 & Putrajaya \\
\hline S9 & $\begin{array}{l}\text { Speech by YAB Tan Sri Dato’ Hj } \\
\text { Muhyiddin bin Hj Mohd Yassin - } \\
\text { Prime Minister }\end{array}$ & Covid-19 & 1 May 2020 & Putrajaya \\
\hline S10 & $\begin{array}{l}\text { Speech by YAB Tan Sri Dato’ Hj } \\
\text { Muhyiddin bin Hj Mohd Yassin - } \\
\text { Prime Minister }\end{array}$ & Covid-19 & 10 May 2020 & Putrajaya \\
\hline S11 & $\begin{array}{c}\text { Speech by YAB Tan Sri Dato’ Hj } \\
\text { Muhyiddin bin Hj Mohd Yassin - } \\
\text { Prime Minister }\end{array}$ & $\begin{array}{c}\text { In Conjunction } \\
\text { with the Prihatin } \\
\text { Rakyat Economic } \\
\text { Stimulus Package } \\
\text { (Prihatin) }\end{array}$ & 27 March 2020 & Putrajaya \\
\hline S12 & $\begin{array}{c}\text { Speech by YAB Tan Sri Dato’ Hj } \\
\text { Muhyiddin bin Hj Mohd Yassin - } \\
\text { Prime Minister }\end{array}$ & $\begin{array}{c}\text { In Conjunction } \\
\text { with the } \\
\text { Additional } \\
\text { Prihatin SME } \\
\text { Economic } \\
\text { Stimulus Package } \\
\text { (Prihatin SME+) }\end{array}$ & 6 April 2020 & Putrajaya \\
\hline S13 & $\begin{array}{l}\text { Speech by YAB Tan Sri Dato’ Hj } \\
\text { Muhyiddin bin Hj Mohd Yassin - } \\
\text { Prime Minister }\end{array}$ & $\begin{array}{l}\text { In conjunction } \\
\text { with the National } \\
\text { Youth Day } \\
\text { Celebration }\end{array}$ & 15 May 2020 & Putrajaya \\
\hline S14 & $\begin{array}{l}\text { Speech by YAB Tan Sri Dato’ Hj } \\
\text { Muhyiddin bin Hj Mohd Yassin - } \\
\text { Prime Minister }\end{array}$ & $\begin{array}{l}\text { In conjunction } \\
\text { with Teacher's } \\
\text { Day } 2020 \\
\end{array}$ & 16 May 2020 & Putrajaya \\
\hline
\end{tabular}


100 Days of Muhyiddin's Government Leadership: A Manifestation of the Continuity of Paternalism Values

\begin{tabular}{|c|c|c|c|c|}
\hline Code & Title of Speech Text Document & Type of Text & Date & Venue \\
\hline S15 & $\begin{array}{l}\text { Speech by YAB Tan Sri Dato' Hj } \\
\text { Muhyiddin bin Hj Mohd Yassin - } \\
\text { Prime Minister }\end{array}$ & $\begin{array}{l}\text { In Conjunction } \\
\text { with the Hari } \\
\text { Raya Aidilfitri }\end{array}$ & 23 May 2020 & Putrajaya \\
\hline S16 & $\begin{array}{l}\text { Speech by YAB Tan Sri Dato’ Hj } \\
\text { Muhyiddin bin Hj Mohd Yassin - } \\
\text { Prime Minister }\end{array}$ & $\begin{array}{c}\text { In Conjunction } \\
\text { with the National } \\
\text { Economic } \\
\text { Regeneration Plan } \\
\text { (PENJANA) }\end{array}$ & 5 June 2020 & Putrajaya \\
\hline S17 & $\begin{array}{c}\text { Teks Ucapan YAB Tan Sri Dato’ } \\
\text { Haji Muhyiddin bin Hj Mohd Yassin } \\
\text { - Perdana Menteri Malaysia }\end{array}$ & $\begin{array}{l}\text { In Conjunction } \\
\text { with the } \\
\text { Execution of } \\
\text { Restoration } \\
\text { Movement } \\
\text { Control Order } \\
\text { (RMCO) }\end{array}$ & 7 June 2020 & Putrajaya \\
\hline $\mathrm{S} 18$ & $\begin{array}{c}\text { Teks Ucapan YAB Tan Sri Dato' } \\
\text { Haji Muhyiddin bin Hj Mohd Yassin } \\
\text { - Perdana Menteri Malaysia }\end{array}$ & $\begin{array}{c}\text { In Conjunction } \\
\text { with the launch of } \\
\text { Population and } \\
\text { Housing Census } \\
\text { Day } 2020\end{array}$ & 7 July 2020 & Putrajaya \\
\hline
\end{tabular}

The speech texts that are selected and are the focus of this study are: i) Political Speech Texts (S1-S2), ii) Covid19 Speech Texts (S3-S10), and iii) Speech Texts in Conjunction with Celebration (S11-S18). All these three texts are also official texts that are accessible and widely covered to the community and policy makers as well as with consistent delivery.

The first reading is done to each speech text to familiarize the researcher with the style of language, method of delivery, and to understand the real meaning that Muhyiddin wanted to convey in his speech text. Then, the second reading is done to identify the speech paragraph that has development value related to local wisdom. The most important thing at this level is to classify the values based on the predefined value dimensions. While the third reading narrows in the paragraphs that have been identified and classified with the value dimension and development values. It is re-read to ensure that the value dimension classification that was set before is accurate and in accordance with the overall meaning of the speech to be delivered.

\section{SERIES AND EXCERPTS OF SPEECH TEXTS}

Table 2 shows the analysis of the central tendency of each speech text of Muhyiddin (S1 to S18) to each value dimension (DR, DC, DW, and DF). There were 18 speech texts of Muhyiddin covering 3 speech series.

Table 2: Analysis of the Central Tendency of Each Speech Text of Muhyiddin to Each Value Dimension

\begin{tabular}{|c|c|c|c|c|c|c|c|c|c|c|c|}
\hline \multirow{2}{*}{$\begin{array}{l}\text { Text } \\
\text { Code }\end{array}$} & \multicolumn{5}{|c|}{$\begin{array}{c}\text { Political and Celebration } \\
\text { Speech Text }\end{array}$} & \multirow{2}{*}{$\begin{array}{l}\text { Text } \\
\text { Code }\end{array}$} & \multicolumn{5}{|c|}{$\begin{array}{c}\text { Covid-19 } \\
\text { Speech Text }\end{array}$} \\
\hline & $\mathbf{D}_{\mathbf{P}}$ & $\mathbf{D}_{\mathbf{C}}$ & $\mathbf{D}_{\mathrm{w}}$ & $\mathbf{D}_{\mathbf{F}}$ & Total & & $\mathbf{D}_{\mathbf{P}}$ & $\mathbf{D}_{\mathbf{C}}$ & $\mathbf{D}_{\mathrm{w}}$ & $\mathbf{D}_{\mathbf{F}}$ & Total \\
\hline S1 & 3 & 3 & 3 & 0 & 9 & S3 & 2 & 3 & 1 & 2 & 8 \\
\hline S2 & 2 & 2 & 2 & 0 & 6 & S4 & 3 & 1 & 0 & 1 & 5 \\
\hline S11 & 3 & 2 & 1 & 1 & 7 & S5 & 2 & 0 & 0 & 0 & 2 \\
\hline $\mathrm{S} 12$ & 1 & 2 & 0 & 6 & 9 & S6 & 8 & 4 & 0 & 2 & 14 \\
\hline $\mathrm{S} 13$ & 0 & 0 & 2 & 0 & 2 & S7 & 3 & 0 & 0 & 4 & 7 \\
\hline S14 & 0 & 0 & 2 & 0 & 2 & S8 & 2 & 0 & 1 & 2 & 5 \\
\hline S15 & 0 & 0 & 3 & 0 & 3 & S9 & 9 & 1 & 4 & 0 & 14 \\
\hline S16 & 0 & 3 & 7 & 1 & 11 & S10 & 3 & 0 & 0 & 2 & 5 \\
\hline S17 & 0 & 1 & 3 & 0 & 4 & & & & & & \\
\hline S18 & 0 & 1 & 2 & 0 & 3 & & & & & & \\
\hline Total & 9 & 14 & 25 & 8 & 56 & Total & 32 & 9 & 6 & 13 & 60 \\
\hline \multicolumn{7}{|c|}{ Total } & 41 & 23 & 31 & 21 & 116 \\
\hline
\end{tabular}

Note:

$\mathrm{DP}=$ Power Oriented Value Dimension $\quad \mathrm{DC}=$ Racial/Community Value Dimension

$\mathrm{DW}=$ Work Ethics Value Dimension $\quad \mathrm{DF}=$ Family Value Dimension

Based on the Tendency Distribution Table above, a total of 116 text passages related to Value Dimensions have been identified. 
The Political Speech Text Series (S1-S2) recorded only 15 text excerpts of the value dimension in total. Nevertheless, it is balanced on every dimension except the family value dimension which was not found in any appropriate text excerpts. The Political Speech Texts (S1-S2) was considered as a text to restore the people's trust in Muhyiddin. His speech aspirations were based on the value of appeal which includes elements of persuasion, sadness, emotion, and hope that can calm the hearts of the people. In his inaugural address on March 2, 2020, he stated:

"Give me the opportunity to leverage my 40 years of experience in politics and government to steer Malaysia towards glory. I offer my soul and body for the country."

(Muhyiddin S1, 2020)

Meanwhile, the Covid-19 Speech Text (S3-S10) was the most dominant speech text. It covered 52 percent (60 text excerpts) of the entire text. Its power oriented value dimension covered 53 percent (32 text excerpts) compared to other value dimensions. The emphasis on the power oriented value dimension can be expected in the event of a pandemic situation affecting the entire world with no previous development experience. In this regard, all kinds of instructions and sources of power in the government are implemented. At the same time, obedience from the community to comply with all instructions is expected. However, this orientation of authority was still embodied by Muhyiddin with instructions that are appealing, and advice. At the same time, it did not run away from the application of work ethics, racism/society, and family values.

"I ask all of you, to adhere to this Restriction of Movement Order. Indeed, it is our collective responsibility to do so, as a citizen who cares for the wellbeing of our families, our communities and hour nation.

(Muhyiddin S4, 2020)

In this case, the power or right, according to Kim (2010), is to give orders, control and make decisions. Authoritarianism is related to the stance and principles that prioritize loyalty to the authorities in a country. It is the most frequently studied aspect of the various lists of Asian values available. This dimension involves a variety of attitudes toward power and authority, including respect for higher authorities and hierarchies, a preference for peace and stability, a priority for strong leadership, and an emphasis on consensus governance over competition and debate. It also involves a long tradition of respect for kings and scholars which is closely related to the tendency to glorify government (Kim, 2010).

Speech Texts in Conjunction with Celebration (S11-S18) focused on specific and focused development efforts. It was found that 61 percent ( 41 text excerpts) of the entire value dimension was dominated by the work ethic value dimension. In the rush of complying with the SOP and dealing with a pandemic, Muhyiddin demanded work ethic to every member of his community so that development work can still be done as best as possible. In a speech in conjunction with the National Youth Day Celebration on 15 May 2020, he called:

"The old life and working styles need to change in accordance with the current situation, especially during the implementation of the Conditional Movement Control Order or CMCO throughout the country. Therefore, the government has taken proactive measures not only to stop the spread of the Covid-19 pandemic but to ensure that the youths are not left behind in their survival".

(Muhyiddin S13, 2020)

Similarly, in his speech in conjunction with Teacher's Day on 16 May 2020 organized:

"The achievement of our country as a whole is still below the average achievement level of OECD countries. This requires our teachers to double their efforts to further boost the quality of our country's education to be on par with the quality of education at the international level."

(Muhyiddin S14, 2020)

In this case, Zakaria (2002) stated that Asian society adheres to strong norms such as self-discipline, hard work, and frugality. These features are so different from the proper emphasis in Latin America that they are praised as contributing to the economic miracle in Asia. It is in contrast to the traditional liberal economic theory which asserts that work is an unpleasant activity and is done solely for the material benefit of the work itself.

\section{“ORIENTIZE POWER” AS MUHYIDDIN'S MAIN VALUE DIMENSION}

The following Figure 1 is an analysis of the tendency of Muhyiddin's text excerpts to each value dimension of the study. 


\section{Text Excerpts}

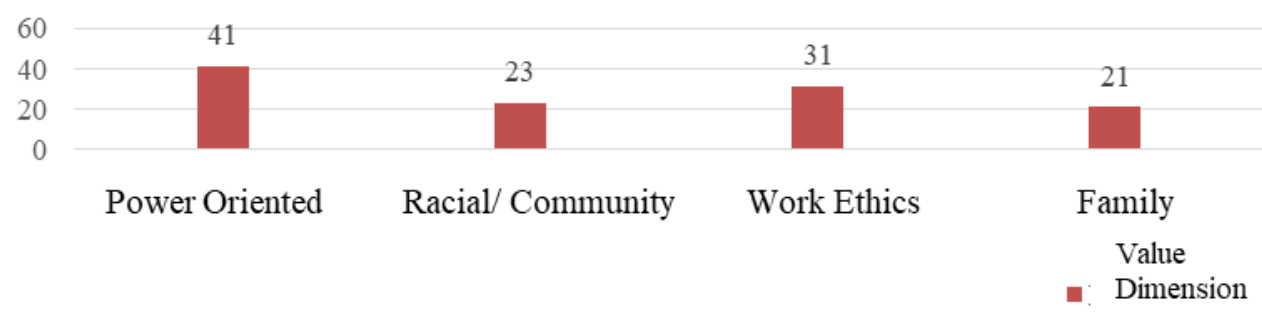

Figure 1: The Tendency of Muhyiddin's Text Excerpts to Each Value Dimension

Based on Figure 1, it is found that the texts of Muhyiddin's speeches were very dominant with the power oriented value dimension. A total of 41 text excerpts were identified in total. Even so, it is not able to prove the true value of his leadership. The results as above occur assuming the urgent need in dealing with the political and social turmoil (pandemic) immediately following the acquisition of leadership. If the assessment is done post Covid-19, it is expected that this trend will change. In fact, the power oriented value dimension was applied thick with the values of advice, persuasion, appeal, and paternal values before ending with a command in the form of power. In Text S6, he said:

"You follow my instruction, You know that this is good for you, your family and the people around you. Your awarness and sincerity in abiding by the rules imposed by the government during this Movement Control Order period is highly commendable.

\section{(25 March 2020)}

According to Fukuyama (2009), the new Asian authoritarianism is most likely not a harsh totalitarian police state, as we all know. Tyranny turned into honor, while the people voluntarily obeyed the authorities and complied with rigid social norms.

For a leader in Asia, the work ethics value dimension has always been a priority in driving the national development. This is evidenced in several studies related to Mahathir in Malaysia and Lee Kuan Yew in Singapore previously. Therefore, the work ethics value dimension still grabbed Muhyiddin's focus within 100 days of his government. A total of 31 text excerpts were identified and this justifies the spirit and way of working based on high moral values and obedience to the government in driving the development of the country collectively. In Text S18 related to the Launch of the Housing Population Census Day on 7 July 2020, he asserted:

"The role and responsibility that must be borne by the government and the people is to ensure the continued development of Malaysia competitively, with integrity and dignity, so that all citizens achieve a decent standard of living and the focus on the development and progress of the country to achieve the developed country status earlier can also be realized"

(Muhyiddin, 2020)

Meanwhile, the racial/community value dimension and the family value dimension have a distribution of values that is almost similar with 23 text passages and 21 text passages, respectively. These two dimensions of value are often interrelated and interdependent with reference to context. Lutfan (2017) stated that in some cases, these two values are interdependent with each other to explain the main values being discussed. For example, strong family values are a basic condition in the formation of superior racial and societal values in Asian society. While loyalty to family and community causes a certain effort or job to be done diligently, thus forming the ethical values of a sustainable work. Loyalty and obedience to a family and community system enable power orientation in a single government to be implemented.

Muhyiddin when delivering a speech (S11) related to the Prihatin Rakyat Economic Stimulus Package stated:

"This unprecedented situation of course requires unprecedented measures. So, my dear brothers and sisters, and the children of this beloved country, whether you are Malay, Chinese, Indian, Sikh, Iban, Kadazan, Dusun, orang asal, please bear with me and my friends in the Cabinet and the Government. We are not perfect but we are doing the best we can to pull through this crisis together, as one nation. God willing, we will come out stronger when this crisis ends and the dust settles. InshaAllah."

(27 March 2020)

Clearly the values of racism/society and family are united in one text and interspersed with the influence of paternalism. Hofstede (1988) in Zurina Mahadi and Hukil Sino (2007) found that, in Southeast Asia, the smallest unit of society is the family (collectivism) rather than the individual. An individual is meaningless without relationships with other individuals in his or her group (family or ethnicity). Mahathir (1999) in his book entitled Kebangkitan Semula Asia argues that the first and most important Asian value is family and community oriented. Asian societies value family and the needs and interests of the society more than individuals and the right to absolute individual freedom. 
More interestingly, the elements of racism and society are not discussed and meant as racism by emphasizing that any one tribe is the most superior. It is a value position that determines that it is important to place the welfare and goals of the group over self-priorities. Jim Baker (2009) in his book Crossroads stated that if there is even an element of individual interest in Asian values, it is used solely for the mutual interest of a larger group. This is clear in the context of economic domination. Next will only continue to create stability, maintaining a society that saves with a high work ethic.

Muhyiddin in a speech at the Global Collaboration to Accelerate New COVID-19 Health Technology on 24 April 2020 stated:

"I am confident that with solidarity, vision and leadership we can unite and get through these dark times together. As a region we have faced multiple crisis before this and I believe, we will once again overcome this and emerge stronger than ever. God-Willing"

(Prime Minister's Office, 2020)

\section{DAYS OF MUHYIDDIN: THE SUMMIT OF PATERNALISM VALUE APPLICATION}

Aycan (2006) in Selvarajah (2020) summarizes five paternalistic leadership dimensions that distinguish them from other leadership theories: (1) Creating a family atmosphere in the workplace (2) Establishing close and individualized relationships with subordinate (3) Getting involved in nonwork domain (4) Expecting loyalty (5) Maintaining authority or status. It is emphasized that paternalism is an embedded Asian value (Yukongdi, 2010; Westwood, 1997) and, from a positive perspective, it is the driver of economic growth in many East-Asian economies (Westwood, 1997). Resultantly, paternalism has had increased attention by both Western and Eastern researchers (Selvarajah et al., 2017; Gelfand, Erez, and Aycan, 2007; Pellegrini and Scandura, 2008).

This paternalistic leadership may be considered irrelevant in this post-modernization and globalization era, but past studies showed that it can still come back and still be so strong. In India, for example, there is the practice of "paternal authoritativeness". It is a situation where the authorities need to be able to anticipate the needs of its people and cultivate faith in the needs and treatment of life as a family like a family member of a leader. For that, the quality of a leader that is needed is wise and knowledgeable about what needs to be done in various situations for the good of his or her people.

Leaders are not only responsible for ensuring political stability, but also for giving good advice and offering assistance to the people (Brislin, 1993, p. 275; Kumar \& Saxena, 1983; Sinha, 1980). A similar decision was reported by Yao (1987) in the People's Republic of China supporting the concept of "paternal authoritativeness"; where leaders need to be strong, effective, and knowledgeable. China's value system and its working style are still dominated by traditional value systems (Low, 2006). Quoting Han (1999) that all the Asian values defined and created by its leaders became a useful tool to validate them as a paternalistic state, bring rapid economic development, and be able to adapt to the changing world.

Indeed, Malaysia under Muhyiddin's leadership has been recognized as one of the most successful countries in controlling and managing the Covid-19 pandemic. Until this article is written, Malaysia has reached the stage of Recovery Movement Control Order (RMCO) which is a phase that begins to allow the people to move and try to start life as usual. More uniquely, the political scenario is also controlled and even each political actor provides close cooperation in dealing with this pandemic. Certainly, the combination of leaders and those led has played an important role. Asian-style leadership full of its own local wisdom justifies this success. In fact, this time, it is covered with one of the most authentic approaches, namely paternalistic leadership.

\section{Conclusion}

Whether he is liked or hated, adored or insulted, Muhyiddin is a legitimate leader and is given legal trust by the highest authority, Yang Di Pertuan Agong to lead Malaysia. This leader who was assumed interim has carried out developments well using his own mould based on local wisdom values. Quoting the YAB Prime Minister's Special Speech Text (S6) as a conclusion to the whole concept of Paternalistic leadership in front of all Malaysians:

"We have tried our best to deal with the crisis we are facing. Let us not forget that the determinant of our success is God Almighty. Therefore, I would like to invite you all to raise your hands and pray to Allah S.W.T so that we, our families, our country and all of mankind are protected by Him.”

(Prime Minister's Special Speech; 25 March 2020)

\section{References}

1. Abdul Mua'ti. (2007). "Pemikiran Tun Dr Mahathir Mohamad". Kuala Lumpur: Penerbit Universiti Malaya

2. Akbal (2020). "Muhyiddin: Perdana Menteri Kurang Sangat Berpolitik". From: https://www.bharian.com.my/berita/nasional/2020/06/698510/muhyiddin-perdana-menteri-kurangsangat-berpolitik

3. Fareed Zakaria, (2002). “Asian Values”- Foreign Policy, November 1, 38-39 
4. Francis Fukuyama. (2009). "Penamat Sejarah dan Manusia Terakhir". (Penterjemah: Shamsiah Md Said). Kuala Lumpur: Institut Terjemahan Negara Malaysia.

5. Gelfand, M. J., M. Erez, and Z. Aycan. 2007. "Cross-Cultural Organizational Behavior.” Annual Review of Psychology 58: 479-514. doi:10.1146/annurev.psych.58.110405.085559

6. Han, S. J. (Ed.). (1999). "Changing Values In Asia - Their Impact on Governance and Development". Tokyo: Japan Center for International Exchange Inc

7. Jim Baker. (2008). "Crossroads: A Popular History of Malaysia and Singapore.” Singapore: Utopia Press Ltd

8. Kim, S.U.(1988). "The role of social values and competitiveness in economic

9. growth:With special reference to Korea", in Sinha, D\&Kao, S.H.R. (Eds),

10. Low, K.C.P. (2006). "Father leadership: the Singapore case study. Managemnet

11. Decision, 44(1), p 89-104. Doi 10.1108/00251740610641481

12. Lutfan Jaes. (2017). "Akal Budi Tempatan Dalam Pengurusan Pembangunan Soeharto, Mahathir dan Lee Kuan Yew". Thesis PhD. Universiti Utara Malaysia.

13. Mahathir, M. (1999). "Kebangkitan Semula Asia". Kelana Jaya: Pelanduk Publication

14. Mohd Tap Salleh, Zakaria Ahmad dan Syed Zulflida Syed Mohd Noor. Penyunting. (1993). "Nilai dan Etika dalam Perkhidmatan Awam". Kuala Lumpur: Institut Tadbiran Awam Negara (INTAN).

15. Pellegrini, E. K., and T. A. Scandura. 2008. "Paternalistic Leadership: A Review and Agenda for Future Research.” Journal of Management 34 (3): 566-593. doi:10.1177/0149206308316063.

16. Selvarajah, C., D. Meyer, and P. Dahanayake. 2020. "Profiling the paternalistic manager: leadership excellence in the Philippines." Asia Pacific Business Review 18 (4): 649-674. doi:10.1080/13602381.2020.1770467

17. Selvarajah, C., D. Meyer, R. Roostika, and S. Sukunesan. 2017. "Exploring Managerial Leadership: Engaging Asta Brata, the Eight Principles of Indonesian Statesmanship.” Asia-Pacific Business Review 23 (3): 373-395. doi:10.1080/13602381.2016.1213494.

18. Tun Sheikh Engku Bendahara (2016). "Tan Sri Muhyiddin Yassin":From; http://sejarahtunsheikh.blogspot.com/2010/01/tan-sri-dato-hj-muhyiddin-yasin-kini.html

19. Westwood, R.I. , and A. Chan 1992 'Headship and leadership' in Organisational behaviour: Southeast Asian perspectives. R. I. Westwood (ed.), 118-143. Hong Kong: Longman .

20. Yukongdi, V. 2010. "A Study of Thai Employees' Preferred Leadership Style.” Asia Pacific Business Review 16 (1-2): 161-181.

21. Zurina Mahadi dan Hukil Sino (2007) "Hubungan nilai masyarakat \& pembangunan: satu Analisa". MALIM: Jurnal Pengajian Umum Asia Tenggara, 8. pp 77-94. ISSN 1511-8393 